\title{
Ю.Г. Швецов
}

\section{О БЮРОКРАТИЧЕСКОМ ГОСУДАРСТВЕ И ЭКОНОМИКЕ}

\begin{abstract}
В статье рассматривается проблема бюрократизачии государства и важнейших соииально-экономических последствий этого явления. Раскрывается сущность бюрократии, проанализированы характерные особенности ее функиионирования в РФ, материальная основа бюрократии и ее доминирующее положение в обществе. Сделан вывод о перепрофилировании бюджета на обслуживание интересов бюрократии.

Ключевые слова: бюрократия, государство, бюджетная реформа, бюджетная система, налоговая система.
\end{abstract}

Некоторое время назад мы уже привлекали внимание специалистов к проблеме бюрократизации российского общества [4]. С тех пор в лучшую сторону ничего не изменилось, по-прежнему объективная потребность развития национального государства наталкивается на сопротивление составляющих его бюрократических сил.

Авторитарное государство как выразитель интересов правящего класса. Длительный путь исторического развития экономической деятельности людей в качестве аксиомы вывел следующую закономерность: в конечном итоге в обществе остаются только те формы организации общественного воспроизводства, а также только те его участники, которые оказались наиболее эффективными в своей сфере деятельности.

Речь идет как о методах организации производства различных форм собственности (частной, акционерной государственной, смешанной и т.п.), так и об основных субъектах экономических процессов (домашних хозяйствах, предприятиях, государствах). Поэтому последнее, как и любой другой общественный институт, существует исключительно потому, что в этом качестве он необходим обществу. К примеру, центральные органы власти призваны обеспечивать безопасность и внутренний порядок в стране, а также формулировать законы, определяющие характер и механизм существования и развития национальной экономической системы.

Таким образом, появление государства вызвано, в частности, необходимостью создавать условия для плодотворной деятельности хозяйствующих субъектов. В этой связи цель государства, его рациональность связаны непосредственно со служением интересам экономических агентов и населения. И оценка эффективности деятельности государства всегда зависит от степени реализации этой функции.

При этом наиболее приоритетной сферой деятельности государства является производство и предложение общественных благ, которые, в отли- 
чие от частных, производимых в рыночных условиях, гораздо дешевле для общества концентрировать в руках именно государства. А раз это так, то в обществе должен существовать механизм перераспределения средств в пользу государства, которые и будут обеспечивать исполнение им своих функций.

Как известно, государственные финансы - это система сбора и использования денежных средств на национальные нужды. Из самого определения вытекает одна из важнейших предпосылок их существования - формирование общественных потребностей и их ранжирование, т.е. определение тех ключевых сфер, на которые, собственно, и предполагается тратить «общие» (государственные) деньги.

В общем виде направления расходования финансовых ресурсов, привлекаемых государством, зависят от тех функций, которые оно выполняет в обществе. В демократическом обществе государство преимущественно представляет интересы населения, и здесь важна уже только сама процедура выявления этих интересов и формирования их как государственных. Как правило, это происходит в рамках соответствующих обсуждений в органах представительной власти различных уровней, избираемых населением. Поэтому для формирования государственных финансов необходимо признание и определение таких государственных потребностей, которые должны быть удовлетворены прежде всего в интересах всего общества.

В авторитарном же государстве оно само определяет круг своих полномочий, а стало быть, и объем финансовых ресурсов, мобилизуемых на свои нужды. Здесь уже общественные, в широком смысле слова, и государственные потребности, как правило, не совпадают, между ними всегда есть ощутимые различия.

Они заключаются в том, что государственные потребности обычно носят опосредованный правящим классом характер, так как население (отдельные индивидуумы, семьи, различные группы) от удовлетворения таких потребностей силами государственной власти отстранено, поэтому они далеки от повседневных нужд рядовых граждан. В этом случае государственные финансы как совокупность денежных отношений обслуживают интересы исключительно властной группы общества в противовес общественным, т.е. интересам проживающей в данной стране основной массы населения. Прямыми следствиями этого становятся стремление государственного аппарата и его чиновников к раздуванию расходов на свое содержание, низкая эффективность государственного регулирования экономики, замедление темпов экономического роста, обнищание населения и т.п.

Следовательно, говоря о всевозрастающей роли современного государства в регулировании рыночной экономики, неправомерно смешивать функции собственно государства и чиновников, находящихся на его службе на всех уровнях иерархического управления. Их интересы являются диаметрально противоположными в авторитарном обществе, и их сближение начинает происходить только по мере перехода последнего на принципы демократического развития. 
Формирование потребностей класса, занимающего доминирующее положение в государстве, всегда происходит в условиях острой конкурентной борьбы за денежные средства бюджетов всех уровней. Это обусловлено тем, что в системе интересов, связанных с распределением общегосударственных финансовых ресурсов, существуют всевозможные структуры управления, т.е. система ведомств, министерств, региональных властей, которые занимают различные места в иерархии государства. Каждая из таких структур заинтересована в решении определенных конкретных проблем в свою пользу, отсюда и разные точки зрения на объем и сроки финансирования тех или иных объектов и мероприятий.

Помимо этого, каждое ведомство стремится к самосохранению и повышению своего влияния, что также сказывается на распределении финансовых ресурсов, ибо государство в реальности - это и есть определенный набор ведомств и организаций. Поэтому между отдельными ведомствами и уровнями государственной власти всегда присутствует конфликт интересов.

Скажем, управляющие органы субъектов Федерации требуют у федеральных властей финансовой поддержки, приводя соответствующие аргументы. Но эти же органы будут доказывать местным (муниципальным) властям чрезмерность их финансовых требований к ним при формировании местных бюджетов. Поэтому разногласия по финансовым вопросам внутри государственного аппарата - это совершенно типичная ситуаци, и возникающие здесь противоречия разрешаются по законам главенствующего положения в иерархии власти.

Подчеркнем, что в демократическом обществе государство выполняет функции, направленные на удовлетворение потребностей всего населения безотносительно принадлежности отдельных членов общества к каким-либо властным структурам, в авторитарном же государстве оно обслуживает интересы преимущественно правящего класса, запросы всего остального населения страны учитываются исключительно по остаточному принципу. В последнем случае реальностью становится полная утрата контроля общества над бюрократией, превратившейся в автократический класс.

Таким образом, бюрократия служит одним из крайних вариантов несовершенства государственного вмешательства в экономику, в основе которого лежит неспособность обеспечить эффективное распределение и использование общественных ресурсов.

Прямым следствием этого является проявление двух взаимосвязанных процессов. Во-первых, общественное благосостояние неизбежно сокращается за счет недопотребления определенных благ вследствие господства бюрократии и предоставления их ею по более высокой цене. Во-вторых, часть потенциального дохода государства от продажи общественных благ теряется за счет недопотребления населением, а другая его часть переходит к бюрократии, что и приводит к чистым потерям (убыткам) для общества.

Важнейшим элементом бюрократической системы управления является использование общегосударственных ресурсов для личной выгоды в ситу- 
ации, когда общество возлагает на чиновника выполнение определенных задач, а последний действует вразрез с общественными интересами в угоду собственным. Иными словами, деятельность чиновника сводится к максимизации его полезности посредством извлечения непроизводительного дохода за счет использования и перераспределения ресурсов, не принадлежащих, но доступных ему.

Бюрократия всегда и везде ищет выгоду от вводимых государством ограничений, регулирующих и контролирующих правил, которые обусловливают функционирование рынка. Поэтому государственные служащие лично заинтересованы в искусственном создании бюрократических барьеров, порождающих дополнительный спрос на их услуги.

Самыми важными факторами, создающими возможность доминирования номенклатуры в обществе, являются монопольный доступ бюрократии к общественным ресурсам и одновременное отсутствие контроля над ней со стороны общества и государства.

Чиновникам нет резона заниматься проблемами развития государства, в том числе социальными, их больше привлекает возможность решать за соответствующее вознаграждение частные проблемы богатых членов общества. Тем самым бюрократия усиливает напряжение в обществе, дискредитирует законы - основной инструмент регулирования государственности.

Российская бюрократия: тенденция роста. Авторитарность российского государственного устройства на основе господства в нем класса чиновников ведет к систематическим негативным просчетам в осуществляемой экономической политике как на законодательном, так и на исполнительном уровне, причем не только и не столько в чрезвычайных обстоятельствах, а в условиях стабильной социально-политической ситуации в стране.

Тотальная бюрократизация властных структур фактически ставит под сомнение существование самого государства, так как снижает его зависимость от населения. Государство начинает функционировать как самостоятельная политическая сила в интересах не всего общества, а той его части, которая привела к власти «свою» политическую силу или группу.

Об этом наглядно свидетельствуют и данные, приводимые в экономической литературе. Уже в 1990-е гг. численность государственного аппарата почти удвоилась. Разрастание количества чиновников продолжилось и в последующие годы: по официальным статистическим данным, в 2005 г. при сокращении общего числа занятых в стране количество работников аппарата управления с 1990 г. возросло в 2 раза [5. С. 198].

Только за один 2006 г. общее количество государственных служащих в нашей стране выросло на полтора миллиона человек. А в 2007 г. расходы на госаппарат увеличились еще в полтора раза. При этом «практически все деньги, сэкономленные Россией на досрочном погашении долгов Западу, попали в эту статью» [7. С. 7].

К началу 2009 г. в России насчитывалось уже 1,7 млн чиновников, по сравнению с 2006 г. их число увеличилось на 240 тыс. чел. [11. С. 8] или на 
$15 \%$. При этом если в последние годы существования СССР один чиновник приходился на 220 жителей, включая младенцев, то к началу 2009 г. эта цифра выросла более чем в 2 раза: на каждые 100 россиян - один бюрократ, не считая бизнес-структур, общественных и партийных организаций [10. С. 5].

По официальным данным, при сокращении общего числа занятых в стране количество работников аппарата управления за период 19962010 гг. увеличилось более чем в 1,7 раза, причем после 2004 г. темпы существенно возросли, достигнув значения 1,9 млн чел. Если же к последним приплюсовать число работающих всех муниципальных служб, государственных корпораций, МУПов, ВГУПов, в силовых структурах, руководящих служащих ряда предприятий с государственным участием и т.п., то набирается не менее 5-6 млн чел., т.е. 3 раза больше [8. С. 8; 12. С. 4; 13. С. 7]. В 2016 г. численность занятых в органах власти и управления увеличилась по сравнению с 2010 г. еще как минимум на 30\% [14].

Эволюция российской бюрократии. Борьба с бюрократическим произволом берет свои истоки с глубокой древности. Еще в Ветхом Завете отмечалось, что «начальник требует подарков, и судья судит за взятки, а вельможи высказывают злые хотения души своей и извращают дело». Платон утверждал: «Я вижу близкую гибель того государства, где закон не имеет силы и находится под чьей-либо властью». Именно от коррупции погиб Древний Рим, несмотря на радикальные меры борьбы с ней: так, судья судил, сидя в кожаном кресле, сделанном из кожи предыдущего судьи-взяточника.

Корни российской бюрократии также уходят в далекое прошлое. Э. Радзинский пишет: «“Кормление” - великий обычай, с него начинается тысячелетнее воровство русской бюрократии, навсегда засевшее в ее генах. Боярин, назначавшийся наместником московского Великого князя, должен был “кормиться" за счет управляемой им области. По прибытии он получал от жителей первый взнос под названием "кто сколько может" - и попробуй ему не дать! Как липку обдирали управляемых, беспощадно. Куда хуже татарского ига были для народа эти “кормления"!.. Но захватившие власть... не только обирали население - они открыто грабили и царскую казну...» [3. С. 116-117].

В свое время царь Иван Грозный разделил страну на две части Опричнину и Земщину. Все лучшие земли, домовладения были переданы в Опричнину, места пустынные и бедные вотчины оказались уделом Земщины. По существу в Опричнине сосредоточились привилегированные слои тогдашнего населения, и именно их интересы обслуживала специально созданная армия - опричники. Любой опричник мог обвинить любого земского в том, что тот ему должен, и земский обязан был платить немедля.

«...С Опричниной Власть обрела главное свойство, делающее ее абсолютной, - страх перед непредсказуемостью и тайной» [3. С. 159].

Не правда ли, ситуация в сегодняшней России напоминает древнерусскую ХУ1 в.? В Опричнину сегодняшнюю входит вся бюрократическая рать вместе со взращенными ею олигархами, в Земщину - мелкие предприниматели и население. И все государственные структуры свято чтят 
свою обязанность служить Опричнине - налоговая и санитарная службы, пожарные и пр., нимало не беспокоясь о людях Земщины.

История авторитетно свидетельствует о неминуемой подверженности процесса бюрократизации аппарата любого государства. Протекая с разной степенью интенсивности, этот процесс неизменно приводит к тому, что бюрократия «встраивается» в систему власти и управления, административно-хозяйственный механизм и аппаратные структуры каждой страны.

Хотя бюрократии всех стран имеют много общих черт, российская номенклатура все же во многом уникальна. При этом она идентична как советской, так и царской. Бюрократии в нашей стране удалось пронести большинство своих обычаев, традиций и ценностей через всю историю государства, несмотря на то, что кадровый ее состав полностью и не раз менялся.

Отличительными чертами российской бюрократии всегда являлись и являются доведенная до предела сложность административной системы, чинопочитание и постоянная ориентация всех чинов, независимо от ранга, на негосударственные доходы. К последнему российских чиновников всегда подталкивала невысокая заработная плата, которая и устанавливаласьто с учетом возможности получения нелегальных, коррупционных доходов. Особую ценность в такой системе имела и имеет не заработная плата, а доходность места.

Еще одной особенностью истинно российского менталитета, заложенной в генах русского человека, является чрезмерное по сравнению с другими странами поклонение большинства граждан государству. Веками воспитанные в условиях его всемогущества, россияне привыкли его идеализировать и приписывать ему все победы и достижения страны. При этом государство выступает в народном сознании как некий абстрактный образ, не связанный с конкретными чиновниками, которые, конечно, могут быть нечестны, несправедливы и корыстолюбивы.

Рядовому россиянину до сих пор несвойственно относиться к государственным служащим и к государству в целом как к нанятым им для выполнения вполне определенных функций работникам. Такое отношение порождает бесконтрольность государственного аппарата перед обществом и поощряет бюрократизацию и коррупцию, а главное - не создает у номенклатуры стимулов для проведения насущных преобразований в политической, экономической и социальной сферах жизнедеятельности общества.

Закономерности бюрократической системы управления. Бюрократическая система управления означает в самом общем случае процесс постепенного отхода деятельности организации от ее уставных (общественно полезных) целей и подчинения закономерностям внутрикорпоративного иерархического развития. Рассмотрим эти закономерности более подробно.

Рост доли государственных расходов в ВВП экономически развитых стран стал закономерностью номер один и получил название закона Вагнера, в соответствии с которым государственные расходы увеличиваются не только в абсолютном, но и в относительном выражении во всех, даже са- 
мых либеральных развитых странах мира. Несомненно, что безудержный рост государственных расходов является негативным фактором экономического развития, за которым скрываются интересы огромной и связанной общими узами армии чиновников.

Важнейшей закономерностью, обусловливающей постоянный и неизбежный рост всех централизованных органов управления и в первую очередь государства, является известный закон о соотношении сложности объекта управления и управляющей им системы. В теории управления он выражается в том, что сложность управляющей системы растет во много раз быстрее, чем сложность объекта управления.

Политика бюрократического аппарата всегда планируется с ориентацией на прошлый опыт, поэтому в ней почти никогда нет места радикальным преобразованиям, предусматривающим нестандартные решения проблем. Все подчинено тактике внесения бюрократией незначительных поправок в действующие организационные элементы: структуры, процессы, технологии и т.п.

Главной целью номенклатуры является консервация ранее достигнутого уровня, поэтому любые новшества и изменения действующего порядка наталкиваются на ее сопротивление, связанное с необходимостью оправдать существующее состояние.

Основой деятельности бюрократического аппарата становятся многочисленные и разнообразные правила и инструкции, которые являются главной причиной консерватизма бюрократической системы управления. Бюрократическое управление не допускает никаких отклонений от жестко формализованного эталона, при нем не могут существовать разного рода нерегламентированные отношения.

Негибкость и немобильность бюрократического управленческого механизма проявляются в том, что он способен успешно действовать только в стереотипных ситуациях, на которые имеются соответствующие инструкции. Новые явления и сложные обстоятельства приводят бюрократию в замешательство, и работа в организации приостанавливается до поступления разъясняющих ситуацию указаний вышестоящего руководства.

Следовательно, бюрократическое управление эффективно только в отношении достаточно простых объектов и нерезультативно в сложно дифференцированных системах. Бюрократический централизм постоянно стремится к унификации всех управленческих элементов, вопреки сложности и многообразию реально существующих объектов, а потому попросту не способен обеспечить грамотное и оперативное руководство ими, требующее мгновенного принятия решений.

Для бюрократической организации это означает увеличение числа различных подразделений, а также создание более изощренной иерархической структуры соподчиненности и, в конечном итоге, многократное увеличение численности аппарата управления.

Однако разрастание числа чиновников не в состоянии обеспечить достаточно надежную базу для эффективного управления различными объектами. Поэтому этот кибернетический закон, по существу, свидетельствует 
об ограниченности роста и возможностей централизованной системы управления.

Третьей закономерностью бюрократической системы управления является то, что важнейшей целью функционирования организации становится сохранение и расширение ее влияния в экономической, административной и политической системе общества.

Это объясняется тем, что руководство и члены любой организации в ее благополучии и расширении видят залог собственного процветания. В частности, государственная организация работает не только и не столько в интересах учредившего ее общества, сколько в интересах работающих в ней чиновников.

Государство, являющее собой громадный организационный механизм, состоит из множества подобных организаций, каждая из которых, как пауки в банке, борется за самосохранение и расширение сферы своего действия всеми доступными методами.

При этом государственные организации борются за власть и собственное влияние в основном бюрократическими методами. Поэтому каждая из них стремится минимизировать ответственность за принятые ею решения; постоянно увеличивать численность своих сотрудников и наращивать объем предоставляемых ей со стороны государства финансовых и материальных ресурсов.

Огромная армия чиновников, представляющих тысячи различных организаций, постоянно и целенаправленно доказывает необходимость увеличения штатов именно их организации и государственных расходов исключительно на контролируемых ими направлениях.

Следующая закономерность может быть почерпнута из законов Паркинсона. В соответствии с одним из них любая бюрократическая организация вырастет настолько, насколько ей позволят внешние условия. По Паркинсону, бюрократическая организация сама находит себе работу и любая работа, независимо от ее объема, может заполнить собой все отведенное ей время. Поэтому если организация хотя бы на время выведена из-под внешнего общественного контроля, она тут же начнет расширяться, независимо от ее функций, целей и необходимого объема работы.

Значимость каждого чиновника в бюрократической системе определяется прежде всего количеством подчиненных. Поэтому он заинтересован в увеличении числа подчиненных и уменьшении числа соперников, претендующих на его место. Аналогичным образом его подчиненные так же стремятся сначала заполучить, а потом и расширить собственный штат работников. Именно так и происходит рост чиновничьей пирамиды.

Чиновник расширяет сферу собственной деятельности, одновременно пытаясь увеличить свое влияние и власть, при этом всегда обосновывая это производственной необходимостью. Переплетения устремлений различных чиновничьих группировок к власти приводят к устойчивому росту бюрократических организаций.

Закономерностью является и то, что бюрократическая конкуренция принципиально отличается от коммерческой. Если предприниматель полу- 
чает прибыль, когда он поставляет на рынок продукцию с меньшей себестоимостью или лучшего качества, то доход и значимость чиновника практически полностью зависят от занимаемого им места, должности и связанных с ней видимых и невидимых льгот.

Когда предприниматель занят внедрением различных инновационных разработок, направленных на снижение себестоимости продукции и увеличение ее прибыли, то законы коммерческой конкуренции побуждают его следовать интересам всего общества.

При бюрократической же конкуренции чиновник занят пустопорожними по сути и ничего не значащими для общества бюрократическими инновациями, увеличивающими значимость его позиции на служебной лестнице. Эти инновации, как правило, связаны с процессом документооборота в данной организации. Придать им большую значимость возможно путем увеличения потоков служебной документации с обязательными процедурами согласований, визирований и т.п.

Тем самым поток бумаг безмерно расширяется, что является обоснованием для увеличения числа сотрудников и дополнительного финансирования организации. В результате, в отличие от предпринимателя, чиновник, внешне работая как бы для достижения общественно необходимых целей организации, на самом деле наносит обществу ущерб, требуя от него все больше и больше средств на собственное содержание.

Номенклатурные работники объединены только желанием сохранить и упрочить положение своей организации в административной системе, общественно значимые ценности для них значения не имеют.

И поскольку положение большинства бюрократических организаций в обществе, как правило, стабильно, то цели самосохранения не имеют для них решающего значения, позволяя концентрировать усилия на собственном карьерном росте путем стандартного набора приемов бюрократической конкуренции: служебных интриг, личных связей, подхалимства и др.

Следующая закономерность - властно-иерархическая форма бюрократического управления. Власть номенклатуры можно представить в виде пирамидальной структуры, на самом верху которой находятся чиновники, наделенные максимальными правами и полномочиями, а все последующие ступени занимают аппаратчики с их все меньшим и меньшим набором.

При бюрократической системе управления, в которой место в иерархии определяется количеством служебных прав и привилегий, высшая инстанция является всевластной и одновременно бесконтрольной со стороны как общества в целом, так и более низких структур бюрократии.

Естественным следствием властно-иерархической формы бюрократического управления является игнорирование чиновниками потребностей общества в угоду собственным интересам и интересам иерарха. Поэтому важнейшей составляющей процесса бюрократического управления выступает стремление чиновника к укреплению своего положения на иерархической лестнице власти с тем, чтобы использовать его в своих частных интересах, удовлетворяя собственные потребности. 
Номенклатурный работник, занимающий невысокое место в официальной иерархии, будучи экспертом или советником в той или иной области, в подавляющем числе случаев распоряжается своим служебным положением согласно собственным предпочтениям, пренебрегая общественной полезностью, что, естественно, снижает эффективность функционирования любой организации.

Закономерностью бюрократической системы управления можно назвать и так называемую «систему корпоративного рабства». Основой функционирования любой государственной структуры является закрепление зависимости денежного содержания работника от стажа его трудовой деятельности в данной структуре. Карьерный рост большинства сотрудников прямо обусловлен длительностью трудовой деятельности в организации таким образом, чтобы путь от рядового работника до руководителя структурного подразделения совпадал по срокам с периодом завершения трудовой активности, т.е. с предпенсионным возрастом. Большая часть времени в бюрократических структурах уходит не на собственно трудовую деятельность, а на многочисленные совещания, планерки, комиссии, сопровождающиеся немыслимым количеством документооборота.

Противодействие систематическому общественному надзору является следующей характерной особенностью бюрократического управления, проявляющейся в том, что бюрократия старается быть субъектом, а не объектом контроля. Это связано с тем, что чиновник всегда находится в выигрышном положении по сравнению с другими гражданами, на стороне которого находится профессиональная информация (доступ к разного рода нормативным актам, ведомственным инструкциям, служебным материалам и т. д.) Отсутствие доступа к этой информации вынуждает людей платить чиновнику мзду, которая и составляет основной доход бюрократа.

С другой стороны, чиновники осуществляют административный контроль в своем ведомстве, усиливая его над действиями подчиненных и ослабляя над собой со стороны вышестоящих руководителей. Однако номенклатурные работники всегда находят компромисс между собой, что неизбежно формализует сам процесс контроля.

Поэтому многочисленные служебные нарушения чиновников редко сопровождаются их отставками. Административные проверки почти всегда носят формальный характер и имеют последствия только для опальных аппаратчиков. При этом часто государственная комиссия по расследованию служебных преступлений в реальности оказывается инспекцией по сокрытию их подлинных причин и масштабов. Так бесконтрольность чиновников ведет к безнаказанности их действий

Отсутствие контроля «сверху» в бюрократическом обществе проявляется в невозможности его осуществления одной ветвью высшей власти над другой, что проявляется в слабости судебного, а также законодательного контроля за действиями исполнительной власти.

Отсутствие контроля «снизу» за бюрократией проявляется в ее монополии принимать решения и не нести за них ответственности. Именно таким 
образом номенклатура игнорирует общественное мнение и проявляет индифферентность к последствиям хозяйственной деятельности. Реальные возможности контролирующих действий за административно-управленческим персоналом со стороны общества можно смело оценивать как нулевые. Форм низового контроля не существует вообще, ибо отсутствует какая-либо государственная инициатива для их создания.

Важнейшей закономерностью является бюрократизация бюджетного процесса. Учитывая, что бюджет - это основной источник бюрократической ренты, причем более прибыльный, чем даже бизнес на освоении природных ресурсов на нефть и газ, в России до сих пор не создан эффективный и прозрачный механизм бюджетного процесса. Рискнем предположить, что он и не будет создан, ибо бюрократические структуры в силу своего доминирующего положения в обществе этого не допустят.

При этом в основе всесильности бюрократии российского общества лежат пять важнейших предпосылок, заложенных в основу государственной власти.

Первая из них - это назначаемость работников исполнительных органов власти, что позволяет им оказывать огромное и по существу бесконтрольное влияние на судьбы подведомственного им населения и создает у носителей этой власти чувство кастовости, принадлежности к правящему классу.

Вторая предпосылка основана на том, что исполнительная власть зиждется на праве распределения общественных ресурсов: финансовых, материальных (квоты, земельные участки, недвижимость и др.), административных (различные механизмы распорядительной деятельности).

Третья предпосылка проявляется в том, что создаваемый комбинацией первых двух властный потенциал исполнительной власти провоцирует все растущую коррупцию в обществе.

Четвертая и пятая предпосылки основываются на несовершенстве российского законодательства и огромном количестве существующих подзаконных актов, подразумевающих многовариантность действий чиновников по решению конкретных проблем. Именно поэтому номенклатура ни в коей мере не заинтересована в приведении действующего законодательства в стройную систему, исключающую противоречия и неясности при регламентации различных действий и процедур.

Подчеркнем, что все изложенные закономерности типичны для бюрократической системы управления как процесса и независимы от личностной характеристики самого состава аппарата управления. Бюрократическое управление всегда консервативно, его механизм негибок и немобилен, опирается на властный характер централизации, противодействует систематическому общственному контролю, основывается на политике неравных условий конкуренции, провоцирует коррупцию в обществе.

Бюрократия - правящий класс в российском обществе. В стране нарастает губительная для нее трещина между основным населением и классом номенклатуры. Об этом говорят и данные проведенных в РФ опросов общественного мнения. 
Результаты выполненного учеными Северо-Кавказской академии государственной службы проекта «Административно-политические элиты России» отчетливо продемонстрировали склонность большинства чиновников-респондентов к бюрократической системе управления. Так, каждый четвертый респондент полагает, что использует не более половины рабочего времени на исполнение прямых должностных обязанностей; каждый второй считает возможным удержаться в своей должности лишь при условии установления неформальных отношений с «влиятельными людьми», наличии определенных средств и специфической напористости; каждый пятый сомневается в деловых качествах «новой элиты», а каждый десятый, более того, уверен, что в ее состав вошли «алчные и беспринципные люди, ставящие своими целями только личные интересы».

Такие качества, фигурирующие в предложенном работникам руководящих органов перечне качественных составляющих профессионализма, как порядочность, исполнительность и честность, оказались лишь на шестом-восьмом местах, а объективность - вообще на последнем месте. В структуре же «собственных недостатков» непрофессионализм занял около $17 \%$; коррумпированность, «кумовство» и игнорирование интересов граждан - соответственно 13, 12 и 11\%; ориентация на интересы состоятельного меньшинства - около $8 \%$ [2].

По данным опроса 1500 представителей бизнеса сотрудники Института социологии РАН составили «цифровой портрет» современного российского бюрократа: равнодушие к людям (68\%), продажность $(58 \%)$, безразличие к интересам страны $(41 \%)$, некомпетентность и безответственность (42\%) [1. С. 46].

Это свидетельствует прежде всего о реальном процессе отторжения населения от всей системы органов власти в целом. В условиях все более усиливающегося антагонизма в обществе бюрократия становится все менее дееспособной силой государственного управления. Опасность этого явления для гражданского общества чрезвычайно велика, и кроется она в инерционности самой системы господства номенклатуры, не зависящей от субъективного фактора в управлении. Поэтому простая замена чиновников у рычагов распределения финансовых, имущественных и административных ресурсов проблему не решает.

В РФ существует настоящий антиконституционный беспредел, ибо в реальности действуют совсем иные правила и порядки, чем закрепленные в главном законе государства. Вот только некоторые из разряда явных несоответствий:

- провозглашается многопартийность, в действительности же преобладает диктатура «Единой России»;

- депутатам Государственной Думы запрещено заниматься предпринимательской деятельностью, на самом деле среди депутатов значатся десятки крупных бизнесменов с миллиардными состояниями;

- законы должны приниматься депутатами, а пишут и пробивают их лоббисты, находящиеся на содержании у крупных корпораций; 
- декларируется свобода конкуренции и предпринимательства, а на практике весь российский рынок поделен между несколькими монополистами, которые устанавливают грабительские для населения цены и тарифы.

«Единая Россия» стала в настоящее время партией номенклатуры, под контроль которой полностью попали все этажи вертикали власти: правительство, обе палаты парламента, губернаторы, мэры. Более того, партия власти контролирует парламенты практически всех регионов РФ и большинство муниципалитетов страны. Фактически это означает возвращение времен парткомов, когда без партбилета ни один человек не мог занять пост в сфере государственного управления.

Один из разработчиков Конституции профессор М. Краснов говорит: «За последние годы многие положения Конституции РФ перестали выполняться вообще либо трансформировались до неузнаваемости». Опубликованная им «Красная книга» содержит десятки конституционных прав, которые трактуются не в пользу общества и граждан, а в угоду чиновникам и крупным олигархам. «В стране в открытую идет торговля властью, а при принятии решений приоритет отдается не государственным, а узкокорыстным интересам» [6. С. 8].

Вообще теоретически главной обязанностью государственных чиновников является решение разного рода проблем из повседневной жизни российских граждан. Но взаимоотношения последних с бюрократическими структурами уже традиционно основываются на грубости и безразличии номенклатурных работников, пользующихся тем, что законодательство предоставляет им поистине безграничные возможности для произвола.

При социализме, несмотря на все недостатки этого строя, многие социально-бытовые вопросы трудящихся различными контролирующими органами: парткомами, месткомами, народным контролем - все же решались. Сегодня бюрократические органы оторваны от реальной жизни населения, их больше занимают псевдоглобальные проблемы - политика, мировое лидерство, олимпиада и т.П., которые, в свою очередь, неинтересны большинству граждан страны. В результате все более усиливается и так резкая поляризация интересов и образа жизни бюрократии и населения.

В России система управления государством приобрела ярко выраженную антинародную форму, отличную от цивилизованной модели развитых стран. Веками шлифовавшиеся инструменты европейской и американской демократии (свободные выборы, независимые суды, конкуренция, социально ответственное распределение доходов, свободные профсоюзы) в РФ сильно искажены и дискредитированы.

Десятки миллионов россиян живут все беднее и беднее, но заботиться о них на государственном уровне абсолютно некому. Да и что взять с тех, кто живет от зарплаты до зарплаты, как правило, нищенской? Им можно только ежедневно недоплачивать за то, что они производят. По данным академика РАН Д. Львова, американец за 1 долл. зарплаты производит 1,7 долл. ВВП, а россиянин в 3 раза больше - 4,8 долл. продукта. Такой эксплуатации не знает ни одна страна в мире [9. С. 14]. 
Парадокс: в рамках единого государства одних граждан (богатых) оно защищает, а других (бедных) игнорирует. Вывод очевиден: у олигархов есть средства, которые можно заставить выделить на «государственные» цели (выборы, проведение Олимпиады и пр.). Именно поэтому наше правительство всегда отстаивает и поддерживает интересы крупных бизнесменов - от покупки заводов-гигантов и недвижимости по всему миру до предоставления финансовой помощи в условиях кризиса.

Резюмируя, подчеркнем: государство рядовому российскому гражданину обходится непомерно дорого, при этом помощи от него он не получает практически никакой. Человек своим трудом по существу содержит государство, которое не может быть процветающим по определению, ибо в нем большинство населения бедное.

А что мы вообще знаем о деятельности нашего правительства, кроме статистических показателей, объявляемых им самим? Никому не известно, как вообще подбираются туда кадры, по каким критериям, за что увольняют. Отсутствие ответов на эти, а также многие другие вопросы свидетельствует о непрозрачности и корпоративности российского правительства. А между тем вся деятельность государственных органов должна быть тщательно регламентирована, стать доступной и прозрачной для гражданского и парламентского контроля.

При этом уничижительной критике может быть подвергнута любая из стандартного набора функций, обязательных для выполнения любым государством. И это как нельзя лучше характеризует его нынешнее состояние в РФ, наиболее значимым результатом деятельности которого является затянувшийся кризис в политической, экономической и социальной сферах общественного развития.

Огромный перечень изъянов в осуществлении социально-экономической деятельности государственной номенклатуры позволяет констатировать безнаказанность бюрократии за свои просчеты, полное отсутствие ее ответственности за нанесение ущерба государственным интересам. Это еще одно из доказательств неэффективности российского государства и отсутствия в нем демократических начал.

Бюрократия и реформы. О неспособности бюрократического аппарата эффективно управлять государством наглядно свидетельствуют провальные результаты подавляющего большинства реформ в обществе.

Любая государственная реформа должна проводиться не столько для упорядочения работы исполнительной власти, сколько для повышения действенности функционирования ее структур, желательно не связанного с расширением и усилением властных полномочий по отношению к юридическим и физическим лицам в интересах общества.

Поэтому нельзя ограничиваться оценкой результатов недавно осуществленной административной реформы по числу проанализированных и перераспределенных функций управления, перечню разработанных стандартов и регламентов, снижению затрат на управление и т.п., ибо они являются отражением процесса проведения административной реформы, а не показателями ее эффективности. 
В ходе проведения этой реформы проблема недостатка ресурсов под реализацию государственных полномочий в социальной сфере была решена наиболее «простым» и малоэффективным способом - государство просто сняло с себя ответственность за реализацию этих полномочий, сделало их необязательными, факультативными, переложив их осуществление на общество.

Как результат - с точки зрения решения задачи обеспечения граждан социальными благами федеративная реформа вернулась «на круги своя». Начавшись с попыток разграничения финансовой ответственности Центра, регионов и муниципалитетов, она вернулась к состоянию, при котором за реализацию многих социальных полномочий ответственности не несет ни один из уровней публичной власти. В рамках схемы добровольных и добровольно-принудительных полномочий разобраться, какой уровень власти и за что отвечает перед населением, практически невозможно. Факультативными эти обязательства являются сегодня и для федерального центра. В разряд добровольных полномочий попали многие обязательные полномочия социального порядка.

Все вышесказанное можно с полным правом отнести и к реформе государственных финансов. Опыт ряда зарубежных стран отчетливо свидетельствует о том, что последняя очень сложна и болезненна прежде всего в силу того, что она всегда совмещает в себе объект и субъект преобразований, т.е. требует от органов власти «самореформирования». В РФ же была предпринята попытка перестройки финансовой системы, не затрагивая субъекта ее управления - и закономерно потерпела полный крах.

Ни одна из проводимых в РФ реформ не может рассматриваться как полноценная реструктуризация властных органов управления, ибо в своей основе не была направлена на повышение эффективности управленческих функций, а представляла собой лишь перегруппировку аппаратных структур государственной власти. Скажем, успех административной реформы выражается прежде всего в сокращении численности бюрократического аппарата, но может ли хоть одно наше министерство или агентство претендовать на такое достижение?

Поэтому все проводимые с 1991 г. административные преобразования в нашей стране не изменили негативного отношения общества к федеральной, региональной и местной власти, а все декларируемые экономические и социальные реформы вели лишь к обострению конфликта интересов. Единственным зримым результатом всех реформ становилось расширение популяции аппаратчиков.

О преобладании бюрократической составляющей во всех областях государственных начинаний отчетливо свидетельствуют данные о структуре расходов федерального бюджета за 2001-2016 гг. (табл. 1-4).

Приведенные цифры говорят о том, что федеральная бюджетная политика ведется в полном отрыве от действительных приоритетов социальноэкономического прогресса страны. 
Таблица 1. Структура расходов федерального бюджета за 2001-2004 гг.*

\begin{tabular}{|c|l|c|c|c|c|c|c|c|c|c|}
\hline \multirow{2}{*}{$№$} & \multirow{2}{*}{ Расходы федерального бюджета } & \multicolumn{2}{|c|}{2001} & \multicolumn{2}{|c|}{2002} & \multicolumn{2}{|c|}{2003} & \multicolumn{2}{|c|}{2004} \\
\hline & 1 & 2 & 1 & 2 & 1 & 2 & 1 & 2 \\
\hline 1 & $\begin{array}{l}\text { Государственное управление и } \\
\text { местное самоуправление }\end{array}$ & 3,2 & 0,5 & 2,7 & 0,5 & 2,8 & 0,5 & 3,0 & 0,5 \\
\hline 2 & Судебная власть & 0,9 & 0,2 & 1,0 & 0,2 & 1,0 & 0,2 & 1,2 & 0,2 \\
\hline 3 & Национальная оборона & 18,7 & 3,2 & 14,4 & 2,7 & 15,1 & 2,7 & 15,9 & 2,7 \\
\hline 4 & $\begin{array}{l}\text { Правоохранительная деятель- } \\
\text { ность и обеспечение безопасно- } \\
\text { сти государства }\end{array}$ & 11,3 & 1,9 & 9,3 & 1,7 & 10,5 & 1,9 & 11,7 & 2,0 \\
\hline 5 & $\begin{array}{l}\text { Итого на выполнение традици- } \\
\text { онных функцй } \\
\text { п. 1 + п. 2 + п. 3 + п. 4) }\end{array}$ & 34,1 & 5,8 & 27,4 & 5,1 & 29,4 & 5,3 & 31,8 & 5,4 \\
\hline 6 & $\begin{array}{l}\text { Фундаментальные исследования } \\
\text { и содействие НтП }\end{array}$ & 1,8 & 0,3 & 1,5 & 0,3 & 1,7 & 0,3 & 1,7 & 0,3 \\
\hline 7 & $\begin{array}{l}\text { Промышленность, энергетика и } \\
\text { строительство }\end{array}$ & 3,3 & 0,6 & 5,1 & 1,0 & 2,9 & 0,5 & 3,0 & 0,5 \\
\hline 8 & $\begin{array}{l}\text { Сельское хозяйство и рыболов- } \\
\text { ство }\end{array}$ & 1,8 & 0,3 & 1,3 & 0,2 & 1,3 & 0,2 & 1,3 & 0,2 \\
\hline 9 & $\begin{array}{l}\text { Транспорт, дорожное хозяйство, } \\
\text { связь и информатика }\end{array}$ & 2,8 & 0,5 & 2,2 & 0,4 & 2,2 & 0,4 & 2,1 & 0,3 \\
\hline 10 & $\begin{array}{l}\text { Итого на развитие отраслей ма- } \\
\text { териального производства } \\
\text { (п. 7 + п. 8 + п. 9) }\end{array}$ & 7,9 & 1,4 & 8,8 & 1,6 & 6,4 & 1,1 & 6,4 & 1,0 \\
\hline 11 & Образование & 4,1 & 0,7 & 4,0 & 0,7 & 4,2 & 0,7 & 4,5 & 0,7 \\
\hline 12 & $\begin{array}{l}\text { Культура, искусство и кинемато- } \\
\text { графия }\end{array}$ & 0,5 & 0,1 & 0,5 & 0,1 & 0,6 & 0,1 & 0,6 & 0,1 \\
\hline 13 & $\begin{array}{l}\text { Здравоохранение и физическая } \\
\text { культура }\end{array}$ & 1,7 & 0,3 & 1,5 & 0,3 & 1,7 & 0,3 & 1,8 & 0,3 \\
\hline 14 & $\begin{array}{l}\text { Итого на общественно значимые } \\
\text { цели (п. 11 + п. 12 + п. 13) }\end{array}$ & 6,3 & 1,1 & 6,0 & 1,1 & 6,5 & 1,1 & 6,9 & 1,1 \\
\hline 15 & Социальная политика & 8,5 & 1,4 & 23,6 & 4,4 & 5,9 & 1,0 & 5,7 & 0,9 \\
\hline 16 & $\begin{array}{l}\text { Обслуживание государственного } \\
\text { долга }\end{array}$ & 17,5 & 3,0 & 11,2 & 2,1 & 9,4 & 1,7 & 7,6 & 1,3 \\
\hline 17 & $\begin{array}{l}\text { Финансовая помощь бюджетам } \\
\text { других уровней }\end{array}$ & 17,4 & 3,0 & 15,5 & 2,9 & 33,8 & 6,0 & 33,5 & 5,6 \\
\hline 18 & Прочие расходы & 6,5 & 1,1 & 6,2 & 1,3 & 6,9 & 1,3 & 6,4 & 1,1 \\
\hline 19 & Итого & 100 & 17,1 & 100 & 18,8 & 100 & 17,8 & 100 & 16,7 \\
\hline
\end{tabular}

* Рассчитано по данным [15]; 1 - \% к итогу; 2 - \% к ВВП.

Таблица 2. Структура расходов федерального бюджета за 2005-2008 гг., \% к итогу*

\begin{tabular}{c|l|c|c|c|c}
\hline № & \multicolumn{1}{|c|}{ Расходы федерального бюджета } & 2005 & 2006 & 2007 & 2008 \\
\hline 1 & $\begin{array}{l}\text { Функционирование Президента РФ, Правительства } \\
\text { РФ, органов государственной власти и местного са- } \\
\text { моуправления, финансовых, налоговых, таможенных } \\
\text { органов и органов финансового надзора }\end{array}$ & 2,6 & 3,1 & 3,3 & 2,8 \\
\hline 2 & Судебная система & 1,2 & 1,4 & 1,3 & 1,2 \\
\hline 3 & Национальная оборона & 16,5 & 15,9 & 13,9 & 12,7 \\
\hline 4 & $\begin{array}{l}\text { Национальная безопасность и правоохранительная } \\
\text { деятельность }\end{array}$ & 12,8 & 12,8 & 11,1 & 11,3 \\
\hline
\end{tabular}




\begin{tabular}{c|l|c|c|c|c}
\hline № & \multicolumn{1}{|c|}{ Расходы федерального бюджета } & 2005 & 2006 & 2007 & 2008 \\
\hline 5 & $\begin{array}{l}\text { Итого на выполнение традиционных функций (п. 1+ } \\
\text { п. 2 + п. 3 + п. 4) }\end{array}$ & 33,1 & 33,2 & 29,6 & 28,0 \\
\hline 6 & Фундаментальные исследования & 0,9 & 1,0 & 0,9 & 0,9 \\
\hline 7 & Национальная экономика & 7,1 & 8,0 & 11,6 & 13,3 \\
\hline 8 & Сельское хозяйство и рыболовство & 0,5 & 0,6 & 0,4 & 0,8 \\
\hline 9 & Транспорт, связь и информатика & 1,3 & 3,2 & 3,1 & 3,3 \\
\hline 10 & $\begin{array}{l}\text { Итого на развитие отраслей материального } \\
\text { производства (п. 7 + п. 8+ п. 9) }\end{array}$ & 8,9 & 11,8 & 15,1 & 17,4 \\
\hline 11 & Образование & 4,6 & 4,9 & 4,9 & 4,3 \\
\hline 12 & Культура и кинематография & 0,6 & 0,8 & 0,7 & 0,6 \\
\hline 13 & Здравоохранение и спорт & 2,5 & 3,4 & 3,3 & 3,3 \\
\hline 14 & Итого на общестенно значимые цели (п. 11+п. 12+ п. 13) & 7,7 & 9,1 & 8,9 & 8,2 \\
\hline 15 & Социальная политика & 5,0 & 4,7 & 3,5 & 4,0 \\
\hline 16 & $\begin{array}{l}\text { Обслуживание государственного и муниципального } \\
\text { долга }\end{array}$ & 5,9 & 4,0 & 2,4 & 2,3 \\
\hline 17 & Межбюджетные трансферты & 35,4 & 35,0 & 31,7 & 37,6 \\
\hline 18 & Прочие расходы & 3,1 & 1,2 & 7,9 & 1,6 \\
\hline & Расситано по данным [15]. & & &
\end{tabular}

* Рассчитано по данным [15].

Наибольший объем ассигнований приходится на выполнение традиционных государственных функций (государственное и местное самоуправление, судебная система, национальная оборона, национальная безопасность и правоохранительная деятельность) - затраты на эти цели в федеральном бюджете увеличились с 27,4\% в 2002 г. до 41,3\% в 2016 г. от их общего числа, все более приближаясь к 50\%-му рубежу.

Таблииа 3. Структура расходов федерального бюджета за 2009-2012 гг., \% к итогу*

\begin{tabular}{c|l|c|c|c|c}
\hline № & \multicolumn{1}{|c|}{ Расходы федерального бюджета } & 2009 & 2010 & 2011 & 2012 \\
\hline 1 & Общегосударственные вопросы & 11,1 & 8,8 & 8,8 & 7,1 \\
\hline 2 & Национальная оборона & 13,7 & 12,3 & 12,6 & 13,9 \\
\hline 3 & $\begin{array}{l}\text { Национальная безопасность и правоохранительная } \\
\text { деятельность }\end{array}$ & 11,0 & 10,4 & 10,7 & 11,5 \\
\hline 4 & $\begin{array}{l}\text { Итого на выполнение традиционных функций } \\
\text { п. 1 + п. 2 + п. 3) }\end{array}$ & 35,8 & 31,5 & 32,1 & 32,5 \\
\hline 5 & Национальная экономика & 13,5 & 17,1 & 12,3 & 16,4 \\
\hline 6 & Жилищно-коммунальное хозяйство & 1,7 & 1,6 & 2,3 & 2,6 \\
\hline 7 & Охрана окружающей среды & 0,2 & 0,2 & - & 0,2 \\
\hline 8 & $\begin{array}{l}\text { Итого на развитие отраслей материального производ- } \\
\text { ства (п. 5+ п. 6+ п. 7) }\end{array}$ & 15,4 & 18,9 & 14,6 & 19,2 \\
\hline 9 & Образование & 4,7 & 4,3 & 4,4 & 5,0 \\
\hline 10 & Культура, кинематография и СМИ & 1,2 & 1,1 & 1,2 & 0,8 \\
\hline 11 & Здравоохранение и спорт & 3,7 & 3,6 & 3,4 & 5,0 \\
\hline 12 & $\begin{array}{l}\text { Итого на общественно значимые цели } \\
\text { п. 9+ п. 10+ п. 11) }\end{array}$ & 9,6 & 9,0 & 9,0 & 10,8 \\
\hline 13 & Социальная политика & 3,9 & 3,4 & 3,4 & 28,6 \\
\hline 14 & Средства массовой информации & - & - & - & 0,5 \\
\hline 15 & Обслуживание государственного и муниципального долга & - & - & - & 2,4 \\
\hline 16 & Межбюджетные трансферты & 35,3 & 37,2 & 40,9 & 6,0 \\
\hline * Рассчитано по данным [15]. & & & &
\end{tabular}


Традиционно скудным остается финансирование общественно значимых отраслей - образования $(4,1-4,5 \%$, или $0,7 \%$ ВВП в 2001-2004 гг., 4,9$4,3 \%$ в 2005-2008 гг., 4,7-5,0\% в 2009-2012 гг. и 5,0-3,6\% в 2013-2016 гг.), культуры $(0,5-0,6 \%$, или $0,1 \%$ ВВП в 2001-2004 гг. и 0,6 в 2005-2008 гг., $1,2-0,8 \%$ в $2009-2012$ гг. и $0,7-0,5 \%$ в 2013-2016 гг.), здравоохранения и спорта $(1,7-1,8 \%$, или $0,3 \%$ ВВП в 2001-2004 гг. и $2,5-3,3 \%$ в $2005-$ 2008 гг., 3,7-5,0\% в 2009-2012 гг. и 4,3-3,5\% в 2013-2016 гг.).

Таблица 4. Структура расходов федерального бюджета за 2013-2016 гг., \% к итогу*

\begin{tabular}{c|l|c|c|c|c}
\hline № & \multicolumn{1}{|c|}{ Расходы федерального бюджета } & & 2014 & 2015 & 2016 \\
\hline 1 & Общегосударственные вопросы & 6,4 & 6,3 & 7,2 & 6,7 \\
\hline 2 & Национальная оборона & 15,8 & 16,7 & 20,4 & 23,0 \\
\hline 3 & $\begin{array}{l}\text { Национальная безопасность и правоохранительная } \\
\text { деятельность }\end{array}$ & 15,4 & 14,1 & 12,6 & 11,6 \\
\hline 4 & $\begin{array}{l}\text { Итого на выполнение традиционных функций } \\
\text { (п. 1 п. 2 + п. 3) }\end{array}$ & 37,6 & 37,1 & 40,2 & 41,3 \\
\hline 5 & Национальная экономика & 13,8 & 20,9 & 15,1 & 14,0 \\
\hline 6 & Жилищно-коммунальное хозяйство & 1,3 & 0,8 & 0,9 & 0,4 \\
\hline 7 & Охрана окружающей среды & 0,2 & 0,3 & 0,3 & 0,4 \\
\hline 8 & $\begin{array}{l}\text { Итого на развитие отраслей материального производ- } \\
\text { ства (п. 5 + п. 6+ п. 7) }\end{array}$ & 15,3 & 22,0 & 16,3 & 14,8 \\
\hline 9 & Образование & 5,0 & 4,3 & 3,9 & 3,6 \\
\hline 10 & Культура, кинематография & 0,7 & 0,6 & 0,6 & 0,5 \\
\hline 11 & Здравоохранение & 3,8 & 3,6 & 3,3 & 3,1 \\
\hline 12 & Физическая культура и спорт & 0,5 & 0,5 & 0,5 & 0,4 \\
\hline 13 & $\begin{array}{l}\text { Итого на общественно значимые цели } \\
\text { (п. 9+ п. 10+ п. 11+ п. 12) }\end{array}$ & 10,0 & 9,0 & 8,3 & 7,6 \\
\hline 14 & Социальная политика & 28,7 & 23,2 & 27,2 & 27,9 \\
\hline 15 & Средства массовой информации & 0,6 & 0,5 & 0,5 & 0,5 \\
\hline 16 & Обслуживание государственного и муниципального \\
долга & 2,7 & 2,8 & 3,2 & 3,8 \\
\hline 17 & Межбюджетные трансферты & 5,1 & 5,4 & 4,3 & 4,1 \\
\hline
\end{tabular}

* Рассчитано по данным [15].

Бюджетная политика государства должна соответствовать содержательным целям социально-экономического развития страны. Однако официальный бюджет не способен полноценно выполнять функции перераспределения бюджетных средств между различными сферами национального хозяйства из-за его перепрофилирования на обслуживание интересов бюрократии. За него эту роль сейчас выполняет теневой бюджет. В те сферы национальной экономики, куда государство не вкладывает официальные бюджетные средства (здравоохранение, образование, социальное обеспечение и пр.), деньги идут из теневого сектора экономики.

На наш взгляд, от бюрократии полностью избавиться невозможно, так как она внутренне присуща любому государственному устройству. Однако можно и нужно найти средства, ограничивающие отрицательное влияние класса номенклатуры на жизнедеятельность общества, позволяющие минимизировать неизбежно приносимый бюрократией ущерб. 
При этом коррупционная составляющая бюрократической системы управления в обществе неискоренима в рамках стандартного набора профилактических мер. Требуются, разумеется, более тщательная экспертиза готовящихся законов и постановлений на предмет возможности бюрократического произвола и переход к нормативным актам прямого действия, ограничивающим власть чиновников. Но первоочередными шагами представляются три: это, во-первых, существенное и в кратчайшие сроки сокращение численности работников государственного и муниципального управления; во-вторых, восстановление внешнего контроля над бюрократией; в-третьих, учитывая, что государство неотделимо от бюрократии, а бюрократия от коррупции, лучшим способом уменьшения и той, и другой будет максимально возможное ограничение сферы деятельности самого государства в экономике.

\section{Лuтература}

1. Григорьева T.B. Коррупция в России: история и современность // Сибирская финансовая школа. 2009. № 1 .

2. Лексин В. Административная реформа: федеральный, региональный и местный уровни. Статья $1 / /$ Российский экономический журнал. 2006. № 2. С. 48-52.

3. Радзинский Э. Загадки любви. М. : Аргументы и факты. Экспресс-Сервис, Зебра E, 2005. C. 116-117.

4. Швецов Ю. Бюджет как инструмент воспроизводства бюрократии в России // Вопросы экономики. 2006. № 5. С. 87-96.

5. Труд и занятость в России. М. : Росстат, 2006. С. 198.

6. Аргументы и факты. 2006. № 32 .

7. Аргументы и факты. 2006. № 38 .

8. Аргументы и факты. 2007. № 4.

9. Аргументы и факты. 2007. № 21.

10. Аргументы и факты. 2009. № 4.

11. Аргументы и факты. 2009. № 5.

12. Аргументы и факты. 2009. № 6.

13. Комсомольская правда. 2011. 24-31 марта.

14. URL: regnum.ru/news/2252771.html

15. URL: www. Minfin.ru

Shvetsov Y.G., Dr. Sci. (Economics), professor chairman of department «Economy, finances and credit». Altai state technical university (Barnaul, Russian Federation). E-mail: yu.shvetsov@mail.ru

\section{ABOUT THE BUREAUCRATIC STATE AND THE ECONOMY}

Keywords: bureaucracy, state, budgetary reform, budgetary system, taxation system.

The article considers the problem of bureaucratism of the state and of the most important social and economic consequences of this occurrence.

The essence of bureaucracy has been revealed, characteristic features of its functioning in Russia have been analyzed; the material base of bureaucracy and its dominating status in society have been substantiated. The conclusion about closing process of changing of the budget to service of the interests of bureaucracy has been made. 


\section{References}

1. Grigor'eva T.V. Korrupciya v Rossii: istoriya i sovremennost' //Sibirskaya finansovaya shkola, 2009, № 1, s. 46.

2. Leksin V. Administrativnaya reforma: federal'nyj, regional'nyj i mestnyj urovni. Stat'ya 1 // Rossijskij ehkonomicheskij zhurnal, 2006, № 2, s. 48-52.

3. Radzinskij EH. Zagadki lyubvi. M.: Argumenty i fakty. EHkspress-Servis, Zebra E, 2005, s. 116-117.

4. SHvecov YU. Byudzhet kak instrument vosproizvodstva byurokratii v Rossii // Voprosy ehkonomiki, 2006, № 5, s. 87-96.

5. Trud i zanyatost' v Rossii. - M.: Rosstat, 2006. s. 198.

6. Argumenty i fakty, 2006, № 32, s. 8.

7. Argumenty i fakty, 2006, № 38, s. 7.

8. Argumenty i fakty, 2007, № 4, s. 8.

9. Argumenty i fakty, 2007, № 21, s. 14 .

10. Argumenty i fakty, 2009, № 4, s. 5.

11. Argumenty i fakty, 2009, № 5, s. 8 .

12. Argumenty i fakty, 2009, № 6, s. 4

13. Komsomol'skaya pravda, 2011, 24-31 marta, s. 7.

14. regnum.ru/news/2252771.html.

15. www. Minfin.ru

\section{For referencing:}

Shvetsov Y.G. O byurokraticheskom gosudarstve i ehkonomike [About the bureaucratic state and the economy]. Vestnik Tomskogo gosudarstvennogo universiteta. Ekonomika - Tomsk State University Journal of Economics, 2018, no 44, pp. 305-324. 